\title{
Bobot, Indeks Kuning Telur (IKT), Dan Haugh Unit (Hu) Telur Ayam Ras Setelah Perlakuan Dengan Pembungkusan Pasta Rimpang Temulawak (Curcuma xanthorrhiza Roxb).
}

\author{
Dyah Ayu Maharani Putri, Muhammad Anwar Djaelani dan Siti Muflichatun Mardiati \\ Laboratorium Biologi Struktur dan Fungsi Hewan, Departemen Biologi, \\ Fakultas Sains dan Matematika, Universitas Diponegoro, Semarang \\ Jln Prof. Soedarto, SH,Semarang,50275, Telp: (024)7474754; Fax (024) 76480923
}

\begin{abstract}
Eggs are farm products that provide the greatest contribution to the achievement of community nutritional adequacy. The aims of the research was to an analyzed the quality of eggs in treatment without and with a temulawak rhizome pasta stored at 6,12, and 24 days. This research used 35 eggs consists of 7 treatment and 5 replication, namely $\mathrm{PtT}_{0}$ : as control, a group of eggs without packing temulawak rhizome pasta and without storage, $\mathrm{PtT}_{6}$ : a group of eggs without packing temulawak rhizome pasta after 6 days storage, $\mathrm{PdT}_{6}$ : a group of eggs with packing temulawak rhizome pasta after 6 days storage, $\mathrm{PtT}_{12}$ : a group of eggs without packing temulawak rhizome pasta after 12 days storage, $\mathrm{PdT}_{12}$ : a group of eggs with packing temulawak rhizome pasta after 12 days storage, $\mathrm{PtT}_{24}$ : a group of eggs without packing temulawak rhizome pasta after 24 days storage, and $\mathrm{PdT}_{24}$ : a group of eggs with packing temulawak rhizome pasta after 24 days storage. This research was analyzed used a completely randomized design (CRD). Variables measured were egg weight, yolk indeks, and Haugh Unit (HU). Data obtained from this study were analyzed using analysis of variance (ANOVA) if there is a real difference then continued further test using Duncan test at the level $95 \%$. The result egg weight reducted and yolk index shows was significantly different in $\mathrm{PtT}_{6}, \mathrm{PtT}_{12}, \mathrm{PtT}_{24}$, and $\mathrm{PdT}_{24}$ and Haugh Unit (HU) shows was significantly different in $\mathrm{PtT}_{6}, \mathrm{PtT}_{12}, \mathrm{PtT}_{24}$. Conclusion of this research is gived temulawak rhizome pasta are able to maintain the quality of eggs were observed on days 6,12 , and 24.
\end{abstract}

Key Word : Chicken egg, Temulawak rhizome, Egg quality

\begin{abstract}
Abstrak
Telur merupakan produk peternakan yang memberikan sumbangan terbesar bagi tercapainya kecukupan gizi masyarakat. Penelitian ini bertujuan untuk menganalisis kualitas telur ayam ras dalam perlakuan tanpa dan dengan pembungkusan bahan pasta rimpang temulawak disimpan pada waktu 6, 12, dan 24 hari. Penelitian ini menggunakan 35 butir telur ayam ras terdiri atas 7 perlakuan dan 5 kali ulangan, yaitu $\mathrm{Pt}_{0}$ : sebagai kontrol, kelompok telur ayam ras tanpa pembungkusan pasta rimpang temulawak serta tanpa penyimpanan, $\mathrm{PtT}_{6}:$ kelompok telur ayam ras tanpa pembungkusan pasta rimpang temulawak setelah 6 hari penyimpanan, $\mathrm{PdT}_{6}:$ kelompok telur ayam ras dengan pembungkusan pasta rimpang temulawak setelah 6 hari penyimpanan, $\mathrm{PtT}_{12}$ : kelompok telur ayam ras tanpa pembungkusan pasta rimpang temulawak setelah 12 hari penyimpanan, $\mathrm{PdT}_{12}$ : kelompok telur ayam ras dengan pembungkusan pasta rimpang temulawak setelah 12 hari penyimpanan, $\mathrm{PtT}_{24}$ : kelompok telur ayam ras tanpa pembungkusan pasta rimpang temulawak setelah 24 hari penyimpanan, dan $\operatorname{PdT}_{24}$ : kelompok telur ayam ras dengan pembungkusan pasta rimpang temulawak setelah 24 hari penyimpanan. Penelitian menggunakan Rancangan Acak Lengkap (RAL). Variabel yang diukur adalah bobot telur, indeks kuning telur (IKT), dan Haugh Unit (HU). Data yang diperoleh dari penelitian ini dianalisis menggunakan ANOVA (Analysis of Variance) apabila terdapat perbedaan yang nyata maka dilanjutkan uji lanjut dengan menggunakan uji Duncan pada taraf kepercayaan $95 \%$. Hasil analisis bobot susut telur dan indeks kuning telur (IKT) menunjukkan berbeda nyata pada $\mathrm{PtT}_{6}, \mathrm{PtT}_{12}, \mathrm{PtT}_{24}$, dan $\mathrm{PdT}_{24}$ dan Haugh Unit (HU) menunjukkan berbeda nyata pada $\mathrm{PtT}_{6}, \mathrm{PtT}_{12}$, dan $\mathrm{PtT}_{24}$. Kesimpulan penelitian ini adalah pemberian pembungkusan pasta rimpang temulawak mampu mempertahankan kualitas telur ayam ras yang diamati pada hari ke-6, 12, dan 24
\end{abstract}

Kata Kunci : Telur Ayam, Rimpang Temulawak, Kualitas Telur 


\section{PENDAHULUAN}

Telur merupakan produk peternakan yang memberikan sumbangan terbesar bagi tercapainya kecukupan gizi masyarakat. Sebutir telur mengandung gizi yang cukup sempurna karena mengandung protein dalam jumlah besar dan mudah dicerna, maka telur merupakan bahan pangan yang sangat baik untuk anak - anak dalam masa pertumbuhan juga dapat diberikan kepada orang yang sedang sakit untuk mempercepat proses kesembuhannya (Sudaryani, 2003).

Telur ayam khususnya ayam ras dapat dikonsumsi sehari - hari dan digunakan untuk pengolahan pangan. Sebutir telur memiliki kandungan protein yang berkualitas tinggi, lemak, vitamin, dan mineral bahkan telur juga memiliki fungsi sebagai preparasi makanan yaitu sebagai bahan pengembang (leaven), mengemulsi, mempertebal dan mengikat produk makanan, dan menambah warna (Siregar dkk., 2012).

Telur mengalami penurunan kualitas disebabkan masuknya mikroba-mikroba perusak ke dalam isi telur melalui pori-pori kerabang telur, menguapnya air dan gas karena pengaruh suhu lingkungan, serta ruang penyimpan yang lembab akan menyebabkan kerabang berjamur (Haryono, 2000). Lama penyimpanan menentukan kualitas telur; semakin lama telur disimpan, kualitas dan kesegaran telur semakin menurun (Haryoto, 2010).

Mengurangi dampak penurunan kualitas telur dapat dilakukan dengan mencegah kontaminasi isi telur melalui cara menutup poripori kerabang telur dengan larutan kapur, parafin, minyak sayur, natrium silikat $\left(\mathrm{Na}_{2} \mathrm{SiO}_{4}\right)$ atau air kaca, agar-agar, alumunium foil, getah karet, sabun, gelatin, bahkan getah kaktus (Koswara, 2009). Penyimpanan telur dapat dilakukan pada suhu lemari pendingin di atas suhu $-2^{\circ} \mathrm{C}\left(28^{\circ} \mathrm{F}\right)$ untuk mencegah kerusakan telur yang berdampak pada penurunan kualitas telur juga dapat menghambat pelepasan $\mathrm{CO}_{2}$ beserta air di dalam telur (Suradi, 2006). Penyimpanan telur dapat menggunakan metode simpan kering dan perendaman di dalam cairan (Pamungkas, 2007).

Rimpang temulawak dengan nama ilmiah Curcuma xanthorrhiza Roxb. merupakan salah satu bahan baku obat tradisional yang tersebar di Indonesia dan digunakan dalam pembuatan jamu karena mempunyai manfaat sebagai antioksidan dan anti mikroba. Pengujian khasiat rimpang temulawak dapat diketahui melalui bukti empiris melalui pengujian secara in vitro (Prana, 2008). Uji klinis terhadap manusia bahwa rimpang temulawak memiliki banyak manfaat salah satunya sebagai antioksidan (Badan Pengawasan Obat dan Makanan, 2004). Komponen senyawa yang bertindak sebagai antioksidan adalah flavonoid, fenol dan kurkuminoid (Cahyono dkk., 2011).

Kurkuminoid merupakan pigmen berwarna kuning dari rimpang temulawak mengandung bahan alam dalam bentuk campuran senyawa diarilheptanoid, yakni kurkumin, demetoksi kurkumin, dan bisdemetoksikurkumin (Cahyono dkk., 2011). Kurkumin berkhasiat sebagai penangkal senyawa-senyawa radikal bebas berbahaya karena pada kurkumin terdapat gugus senyawa kimia penangkap radikal bebas yaitu gugus hidroksi fenolik dan gugus $\beta$ diketon (Yusro, 2004; Jayaprakhasha et al., 2006). Senyawa kurkumin dalam rimpang temulawak memiliki sifat anti mikroba (Rahmawati dkk., 2013). Berdasarkan kandungan antioksidan dan anti mikroba yang terdapat didalam rimpang temulawak perlu dilakukan penelitian pasta rimpang temulawak sebagai pembungkus telur ayam ras.

\section{BAHAN DAN METODE}

Penelitian dilaksanakan di Kelurahan Meteseh Kecamatan Tembalang, Semarang. Waktu penelitian dilakukan pada 11 September 2015 sampai 5 Oktober 2015. Bahan yang digunakan dalam penelitian ini meliputi : Telur ayam ras, pasta rimpang temulawak (Curcuma xanthorrhiza Roxb.). Alat yang digunakan antara lain : timbangan digital dengan ketelitian 0,01 gram, jangka sorong, egg tray, kaca datar, penggaris, kertas dan alumunium cup, dan $\mathrm{pH}$ meter. Cara kerja dalam penelitian ini meliputi persiapan alat dan bahan dan pelaksanaan penelitian

Persiapan bahan antara lain :

1. Telur ayam ras dicuci bersih dengan air mengalir, ditimbang menggunakan timbangan digital serta dilakukan pencatatan untuk bobot 
awal sebelum penyimpanan, diberi label, dan dikelompokkan dengan kelompok perlakuan.

2. Telur ayam ras yang telah diberi label dan dikelompokkan sesuai kelompok perlakuan dimasukkan ke dalam egg tray

3. Pembuatan pasta rimpang temulawak dengan bahan rimpang temulawak sebanyak $1,5 \mathrm{~kg}$ dikupas kulitnya; dicuci bersih lalu diparut sampai didapatkan hasil parutan halus.

Pelaksanaan penelitian antara lain

1. Rimpang temulawak yang telah diparut kemudian ditimbang masing-masing sebanyak 100 gram untuk membungkus setiap telur perlakuan.

2. Proses memberi perlakuan telur ayam ras menggunakan bahan pembungkus pasta rimpang temulawak dilakukan satu kali pembungkusan.

3. Telur ayam ras yang telah diberi perlakuan disimpan selama 6, 12, dan 24 hari.

Bahan uji yang digunakan pada penelitian ini adalah telur ayam ras dengan jumlah 35 butir. Sebelum diberi perlakuan, telur ayam ras dicuci bersih dengan air mengalir selanjutnya ditimbang. Penimbangan telur untuk mengetahui bobot awal telur sebelum penyimpanan. Telur ayam ras sebanyak 35 butir ditempatkan menggunakan egg tray, dikelompokkan sesuai dengan kelompok perlakuan, dan disimpan selama 6, 12, dan 24 hari. Variabel yang diamati pada penelitian ini adalah bobot telur, indeks kuning telur (IKT), dan Haugh Unit (HU).

Penelitian ini menggunakan Rancangan Acak Lengkap (RAL). Tiga puluh lima telur dibagi dalam 7 perlakuan dan 5 kali ulangan. Data yang diperoleh dari penelitian ini dianalisis menggunakan uji ANOVA (Analysis of Variance), apabila terdapat perbedaan yang nyata maka dilanjutkan uji lanjut menggunakan uji Duncan pada taraf kepercayaan $95 \%$ (Widyastuti dkk., 2014 dalam Gomez, 2005)

\section{HASIL DAN PEMBAHASAN}

Berdasarkan analisis data penelitian berupa bobot susut telur, indeks kuning telur (IKT), dan Haugh Unit (HU) pada telur ayam ras dengan pembungkusan pasta rimpang temulawak menggunakan uji ANOVA dan uji lanjut Duncan pada taraf kepercayaan $95 \%$ dihasilkan ringkasan hasil penelitian disajikan pada Tabel 1 .

Table 1. Hasil analisis rata-rata bobot susut telur, Indeks Kuning Telur (IKT), dan Haugh Unit (HU) dari telur ayam ras yang telah dibungkus pasta rimpang temulawak dan disimpan dengan waktu berbeda

\begin{tabular}{cccccccc}
\hline \multirow{2}{*}{ VARIABEL } & \multicolumn{7}{c}{ PERLAKUAN } \\
\cline { 2 - 7 } & PtT $_{\mathbf{0}}$ & PtT $_{\mathbf{6}}$ & PdT $_{\mathbf{6}}$ & PtT $_{\mathbf{1 2}}$ & PdT $_{\mathbf{1 2}}$ & PtT $_{24}$ & PdT $_{24}$ \\
\hline $\begin{array}{c}\text { Bobot Susut } \\
\text { Telur }(\%)\end{array}$ & $0.00 \pm 0.00^{\mathrm{a}}$ & $1.12 \pm 0.12^{\mathrm{b}}$ & $0.19 \pm 0.05^{\mathrm{a}}$ & $3.52 \pm 1.51^{\mathrm{c}}$ & $0.63 \pm 0.26^{\mathrm{ab}}$ & $5.35 \pm 0.65^{\mathrm{d}}$ & $1.49 \pm 0.39^{\mathrm{b}}$ \\
\hline $\begin{array}{c}\text { Indeks } \\
\text { Kuning } \\
\text { Telur }\end{array}$ & $0.50 \pm 0.02^{\mathrm{c}}$ & $0.42 \pm 0.06^{\mathrm{b}}$ & $0.51 \pm 0.01^{\mathrm{c}}$ & $0.37 \pm 0.03^{\mathrm{a}}$ & $0.51 \pm 0.01^{\mathrm{c}}$ & $0.34 \pm 0.02^{\mathrm{a}}$ & $0.42 \pm 0.03^{\mathrm{b}}$ \\
\hline Haugh Unit & $98.52 \pm 0.66^{\mathrm{d}}$ & $94.61 \pm 2.90^{\mathrm{c}}$ & $99.39 \pm 0.58^{\mathrm{d}}$ & $88.29 \pm 4.69^{\mathrm{b}}$ & $99.24 \pm 0.69^{\mathrm{d}}$ & $82.65 \pm 4.44^{\mathrm{a}}$ & $98.01 \pm 1.55^{\mathrm{cd}}$ \\
\hline
\end{tabular}

Keterangan : Angka dengan superskrip yang sama dalam satu baris menunjukkan hasil yang berbeda tidak nyata pada taraf signifikansi 5\%. $\mathrm{PtT}_{0}$ : kelompok telur ayam ras tanpa pembungkusan pasta rimpang temulawak serta tanpa penyimpanan, $\mathrm{Pt}_{6}$ : kelompok telur ayam ras tanpa pembungkusan pasta rimpang temulawak setelah 6 hari penyimpanan, $\mathrm{PdT}_{6}$ : kelompok telur ayam ras dengan pembungkusan pasta rimpang temulawak setelah 6 hari penyimpanan, $\mathrm{Pt}_{12}:$ kelompok telur ayam ras tanpa pembungkusan pasta rimpang temulawak setelah 12 hari penyimpanan, $\operatorname{PdT}_{12}:$ kelompok telur ayam ras dengan pembungkusan pasta rimpang temulawak setelah 12 hari penyimpanan, $\mathrm{PtT}_{24}$ : kelompok telur ayam ras tanpa pembungkusan pasta rimpang temulawak setelah 24 hari penyimpanan, dan $\mathrm{PdT}_{24}$ : kelompok telur ayam ras dengan pembungkusan pasta rimpang temulawak setelah 24 hari penyimpanan 
Hasil analisis data bobot susut telur menunjukkan berbeda nyata pada kelompok telur $\mathrm{PtT}_{6}, \mathrm{PtT}_{12}, \mathrm{PtT}_{24}$, dan $\mathrm{PdT}_{24}$ bila dibandingkan dengan kelompok telur $\mathrm{PtT}_{0}$. Kelompok telur tanpa pemberian pembungkus pasta rimpang temulawak $\left(\mathrm{PtT}_{6}, \mathrm{PtT}_{12}\right.$, dan $\mathrm{PtT}_{24}$ ) terjadi penurunan bobot disebabkan selama penyimpanan terjadi penguapan air serta hasil degradasi protein dan mineral dalam telur berupa gas $\mathrm{CO}_{2}$ dari dalam isi telur melalui pori kerabang telur dapat mempengaruhi nilai bobot susut telur. Harahap (2007) menyatakan bahwa pada awal penyimpanan penguapan air dan gas $\mathrm{CO}_{2}$ berlangsung lebih cepat karena jumlah cairan lebih banyak, semakin meningkatnya umur atau waktu penyimpanan menyebabkan persediaan cairan dan gas akan semakin berkurang. Kelompok telur $\mathrm{PdT}_{24}$ menunjukkan berbeda nyata dibandingkan dengan kelompok $\mathrm{PtT}_{0}$. Kelompok telur dengan pemberian pembungkus pasta rimpang temulawak setelah 24 hari penyimpanan $\left(\mathrm{PdT}_{24}\right)$ mengalami penurunan bobot disebabkan pembungkus pasta rimpang temulawak mengering dan retak serta membentuk celah sehingga terjadi penguapan melalui celah retakan.

Nilai rata-rata bobot susut telur pada kelompok telur $\mathrm{PtT}_{6}$ sebesar 1,12 gram, kelompok telur $\mathrm{PtT}_{12}$ sebesar 3,52 gram, kelompok telur $\mathrm{PtT}_{24}$ sebesar 5,35 gram, dan kelompok telur $\mathrm{PdT}_{24}$ sebesar 1,49 gram. Yuwanta (2010) menyatakan bahwa menyatakan bahwa pada suhu penyimpanan $25^{\circ} \mathrm{C}$ dengan kelembaban relatif $70 \%$ akan menyebabkan kehilangan berat $0,6 \mathrm{~g} /$ minggu/butir sedangkan pada suhu $30^{\circ} \mathrm{C}$ telur akan kehilangan berat sebesar $1 \mathrm{~g} / \mathrm{minggu} /$ butir.

Nilai rata-rata bobot telur dalam kualitas baik ditunjukkan kelompok telur $\mathrm{PtT}_{6}$ sebesar 59,57, kelompok telur $\mathrm{PtT}_{12}$ sebesar 59,37, kelompok telur $\mathrm{PtT}_{24}$ sebesar 62,14, dan kelompok telur $\mathrm{PdT}_{24}$ sebesar 61,71 memiliki kualitas baik. Siregar dkk. (2012) menyatakan bahwa telur pada kualitas baik memiliki bobot telur sekitar 50 hingga 70 gram.

Hasil analisis data terhadap indeks kuning telur (IKT) menunjukkan hasil yang berbeda nyata pada kelompok telur $\mathrm{PtT}_{6}$, $\mathrm{PtT}_{12}, \mathrm{PtT}_{24}$, dan $\mathrm{PdT}_{24}$ bila dibandingkan dengan kelompok $\mathrm{PtT}_{0}$. Kelompok telur tanpa pemberian pembungkus pasta rimpang temulawak ( $\mathrm{PtT}_{6}, \mathrm{PtT}_{12}$, dan $\mathrm{PtT}_{24}$ ) terjadi penurunan nilai indeks kuning telur (IKT) disebabkan kandungan air pada putih telur yang berada di sekeliling kuning telur akan terserap ke dalam kuning telur; terjadi berkurangnya permiabilitas membran vitelin menyebabkan kuning telur mengalami pemipihan. Soeparno dkk. (2011) menyatakan bahwa penyimpanan telur menyebabkan terjadinya pemindahan air dari putih telur menuju kuning telur sebanyak $10 \mathrm{mg} / \mathrm{hari}$ pada suhu $10^{\circ} \mathrm{C}$. Tekanan osmotik kuning telur lebih besar dari putih telur sehingga air dari putih telur berpindah menuju kuning telur. Perpindahan air secara terus menerus akan menyebabkan viskositas kuning telur menurun sehingga kuning telur menjadi pipih kemudian akan pecah karena proses pemindahan air ini tergantung pada kekentalan putih telur dan indeks kuning telur (IKT) menurun, kemudian membran vitelin akan rusak dan menyebabkan kuning telur rusak. Kelompok telur $\mathrm{PdT}_{24}$ menunjukkan berbeda nyata dibandingkan dengan kelompok $\mathrm{PtT}_{0}$. Kelompok telur dengan pemberian pembungkus pasta rimpang temulawak setelah 24 hari penyimpanan $\left(\mathrm{PdT}_{24}\right)$ mengalami penurunan nilai indeks kuning telur (IKT) disebabkan waktu simpan bertambah dan pembungkus pasta rimpang temulawak mengering dan retak sehingga terjadi proses penurunan permiabilitas membran vitelin terjadi yang berakibat pada penurunan nilai indeks kuning telur (IKT).

Nilai rata-rata indeks kuning telur (IKT) pada kelompok $\mathrm{PtT}_{6}$ sebesar 0,42 dengan mutu II, kelompok $\mathrm{PtT}_{12}$ sebesar 0,37 dengan mutu III, kelompok $\mathrm{PtT}_{24}$ sebesar 0,34 dengan mutu III, dan kelompok $\mathrm{PdT}_{24}$ sebesar 0,42 dengan mutu II. Badan Standarisasi Nasional (2008) menyatakan bahwa tingkatan mutu indeks kuning telur (IKT) adalah 0,458-0,521 (Mutu I), 0,394-0,457 (Mutu II), dan 0,330-0,393 (Mutu III). 
Hasil analisis data terhadap Haugh Unit (HU) menunjukkan berbeda nyata pada kelompok $\mathrm{PtT}_{6}, \mathrm{PtT}_{12}$, dan $\mathrm{PtT}_{24}$ bila dibandingkan dengan kelompok $\mathrm{PtT}_{0}$. Kelompok telur dengan tanpa pembungkusan pasta rimpang temulawak memiliki pengaruh pada kualitas telur khususnya putih telur. Telur tanpa pembungkusan memiliki pengaruh terhadap suhu dan kelembaban lingkungan sehingga terjadi penyusutan bobot akibat penguapan air dan degradasi protein serta mineral juga mencairnya putih telur akibat rusaknya ovomucin. Melia dkk., 2008 menyatakan bahwa proses penipisan putih telur terjadi akibat interaksi antara enzim lysozyme dengan ovomucin. Derajat keasaman $(\mathrm{pH})$ naik disebabkan $\mathrm{CO}_{2}$ keluar selama penyimpanan sehingga berakibat pada daya larut ovoтисіn berkurang dan kekentalan putih telur rusak

Nilai rata-rata Haugh Unit (HU) pada kelompok $\mathrm{PtT}_{6}$ sebesar 94,61 dengan kualitas AA, kelompok $\mathrm{PtT}_{12}$ sebesar 88,29 dengan kualitas AA, dan kelompok $\mathrm{PtT}_{24}$ 82,65 dengan kualitas AA. United States Departement of Agriculture (2000) menyatakan bahwa nilai Haugh Unit (HU) kurang dari 31 digolongkan kualitas $\mathrm{C}$, Nilai Haugh Unit (HU) antara 31-60 digolongkan kualitas B, Nilai Haugh Unit (HU) antara 60-72 digolongkan kualitas A, dan Nilai Haugh Unit (HU) lebih dari 72 digolongkan kualitas AA).
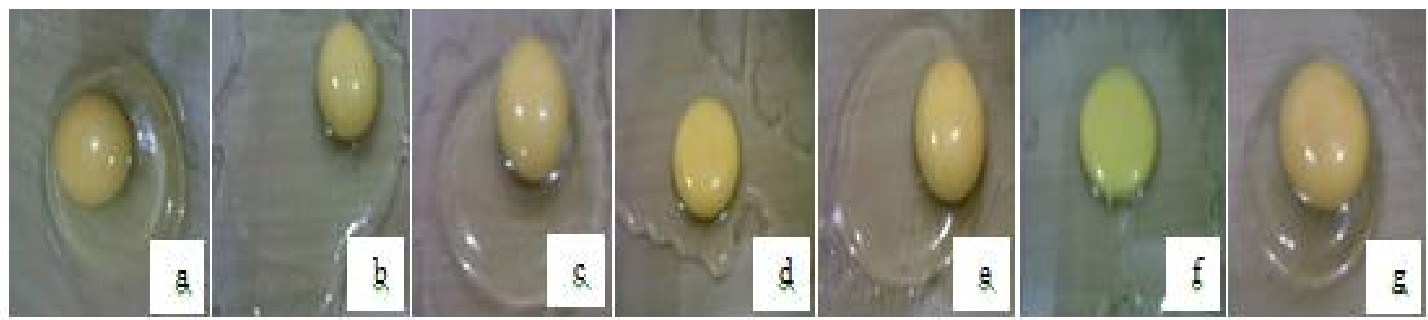

Gambar 1. Morfologi Kuning dan Putih Telur saat pemecahan. Kelompok telur (a) $\mathrm{PtT}_{0}$, (b) PtT 6 , (c) PdT (e) $\operatorname{PdT}_{12}$, (f) $\mathrm{PtT}_{24}$, dan (g) $\operatorname{PdT}_{24}$. 
Morfologi kuning telur setelah mengalami penyimpanan disajikan pada Gambar 1. kelompok $\mathrm{PtT}_{0}$ berwarna kuning cerah, berbentuk bulat utuh, dan terletak di tengah-tengah putih telur. Kelompok telur $\mathrm{PtT}_{6}, \mathrm{PdT}_{6}, \mathrm{PtT}_{12}, \mathrm{PdT}_{12}$, dan $\mathrm{PdT}_{24}$ berwarna kuning cerah, berbentuk bulat utuh, dan letaknya ada yang berada ditengah dan ada yang mulai bergeser dari posisi tengah namun kelompok $\mathrm{PtT}_{24}$ berwarna kuning pucat, berbentuk bulat utuh, terletak menjauh dari posisi tengah, dan mengalami pemipihan. Hal ini diduga karena pengaruh suhu dan kelembaban lingkungan serta lamanya waktu penyimpanan (24 hari penyimpanan) sehingga terjadi penurunan tinggi kuning telur dan elastisitas khalaza.

Morfologi putih telur setelah penyimpanan disajikan pada Gambar 1 Kelompok $\mathrm{PtT}_{0}$ terlihat jernih, kental, mengelilingi kuning telur yang berada ditengah, dan belum terlihat pencairan. Kelompok $\mathrm{PtT}_{6}$ terlihat jernih, mulai mengalami pencairan dalam jumlah sedikit. Kelompok telur $\mathrm{PdT}_{6}$ terlihat jernih, kental, mengelilingi kuning telur dengan erat, dan tidak mengalami pencairan. Kelompok $\mathrm{PtT}_{12}$ terlihat jernih, dan mengalami pencairan pada putih telur dalam jumlah sedikit hingga banyak. Kelompok telur $\mathrm{PdT}_{12}$ terlihat jernih, kental, mengelilingi erat kuning telur, dan tidak mengalami pencairan. Kelompok $\mathrm{PtT}_{24}$ terlihat jernih, dan mengalami pencairan. Kelompok telur $\mathrm{PdT}_{24}$ terlihat jernih, kental, mengikat kuning telur dengan erat, dan tidak terlihat pencairan. Hal ini diduga karena kelompok yang tidak mengalami pembungkusan pasta rimpang temulawak sangat dipengaruhi suhu dan kelembaban lingkungan selama penyimpanan berlangsung serta waktu simpan telur dalam waktu lama (24 hari penyimpanan) sehingga terjadi pencairan putih telur. Hal ini sesuai dengan pernyataan Djaelani (2015) menyatakan bahwa semakin lama penyimpanan menyebabkan menyebabkan putih telur kental menjadi semakin encer akibat penguapan air dan gas karbondioksida $\left(\mathrm{CO}_{2}\right)$.

\section{KESIMPULAN}

Hasil penelitian dengan pembungkusan pasta rimpang temulawak kelompok telur $\mathrm{PtT}_{0}$ sebagai kontrol serta kelompok telur $\mathrm{PtT}_{6}$, $\mathrm{PdT}_{6}, \quad \mathrm{PtT}_{12}, \quad \mathrm{PdT}_{12}, \quad \mathrm{PtT}_{24}, \quad$ dan $\mathrm{PdT}_{24}$ menunjukkan hasil analisis berbeda nyata pada bobot telur dan indeks kuning telur (IKT) pada kelompok $\mathrm{PtT}_{6}, \mathrm{PtT}_{12}, \mathrm{PtT}_{24}$. Nilai Haugh Unit (HU) pada kelompok telur $\mathrm{PtT}_{6}, \mathrm{PtT}_{12}$, dan $\mathrm{PtT}_{24}$ menunjukkan hasil analisis berbeda nyata.

Berdasarkan hal diatas maka dapat disimpulkan bahwa dengan pemberian pembungkus pasta rimpang temulawak pada penelitian ini mampu mempertahankan kualitas telur ayam ras.

\section{DAFTAR PUSTAKA}

Badan Standarisasi Nasional (BSN). 2008. SNI 3926 : 2008 Telur Ayam Konsumsi. BSN. Jakarta.

Cahyono, B., Huda, Khoirul. D. M., dan Limantara, L. 2011. Pengaruh Proses Pengeringan Rimpang Temulawak (Curcuma xanthorriza Roxb) Terhadap Kandungan dan Komposisi Kurkuminoid. Jurnal Reaktor 13(3) : 165-171.

Djaelani, A. M. 2015. Pengaruh Pencelupan pada Air Mendidih dan Air Kapur Sebelum Penyimpanan Terhadap Kualitas Telur Ayam Ras (Gallus L.). Buletin Anatomi dan Fisiologi Jurusan Biologi Fakultas Sains dan Matematika Universitas Diponegoro Semarang 23(1) :24-30.

Gomez, K. A. 2005. Prosedur Statistik Untuk Penelitian Pertanian, edisi kedua. UI Press, Jakarta

Harahap, E. U. 2007. Kajian Pengaruh Bahan Pelapis dan Teknik Pengemasan Terhadap Perubahan Mutu Telur Ayam 
Buras Selama Transportasi dan Penyimpanan. Tesis. Pasca sarjana Institut Pertanian Bogor, Bogor.

Haryono. 2000. Langkah-Langkah Teknis Uji

Kualitas Telur Konsumsi Ayam Ras.

Temu Teknis Fungsional non Penelliti.

Balai Penelitian. Bogor. pp 175-184.

Haryoto. 2010. Membuat Telur Asin. Kanisius. Yogyakarta.

Jayaprakasha, G. K., Jaganmohan, R. L., and Sakariah, K. K. 2006. Antioxidant activities of curcumin, demethoxycurcumin and bisdemethoxycurcumin. Food Chemistry. 98: 720-24.

Koswara, S. 2009. Teknologi Pengolahan Telur. ebookpangan.com.

Melia, S., Juliyarsi, I., dan Africon. 2008. Teknologi Pengawetan Telur Ayam Ras Dalam Larutan Gelatin dari Limbah Kulit Sapi. Fakultas Peternakan Universitas Andalas, Padang.

Pamungkas, P. W. 2007. Evaluasi Kualitas Telur Ayam Ras Hasil Perlakuan Effective Mikroorganisms Selama Penyimpanan. Skripsi. Fakultas Kedokteran Hewan. Universitas Udayana, Denpasar.

Prana, M.S. 2008. The Biologi of Temulawak (Curcuma xanthorrhiza Roxb.). Biopharmaca Research Center Bogor Agricultural University, Bogor. pp 151156.

Rahmawati, N., Sudjarwo, E., dan Widodo, E. 2013. Uji Aktivitas Antibakteri Ekstrak Herbal terhadap Bakteri Escherichia coli. Jurnal Ilmu-ilmu Peternakan 24(3) :24-31.

Siregar, F. R., Hintono. A., dan Mulyani. S. 2012. Perubahan Sifat Fungsional Telur Ayam Ras Pasca Pasteurisasi. Animal Agriculture Journal 1(1) : 521-528.

Soeparno, R.A., Rihastuti, I., dan S. Triatmojo. 2011. Dasar Teknologi Hasil Ternak. Gadjah Mada University Press, Yogyakarta.
Sudaryani, T. 2003. Kualitas Telur. Penebar Swadaya. Jakarta.

Suradi, K. 2006. Perubahan Kualitas Telur Ayam Ras dengan Posisi Peletakan Berbeda Selama Penyimpanan Suhu Refrigerasi. Jurnal Ilmu Ternak 6(2) :136-139.

United States Departement of Agriculture. 2000. Egg Grading Manual. Agricultural Handbook number 75. Washington DC.

Widyastuti, W., Mardiati, M. S., dan Saraswati, R. T. 2014. Pertumbuhan Puyuh (Coturnix coturnix japonica) Setelah Pemberian Tepung Kunyit (Curcuma longa L.) Pada Pakan. Buletin Anatomi dan Fisiologi Jurusan Biologi Fakultas Sains dan Matematika Universitas Diponegoro Semarang 22(2) : 12-20.

Yusro, A. H. 2004. Pengaruh Waktu, Suhu, dan Nisbah Pelarut pada Ekstraksi Kurkumin dari Temulawak dengan Pelarut Etanol. Skripsi. Institut Pertanian Bogor, Bogor. 
Bioma, Juni 2016

ISSN: 1410-8801

Vol. 18, No. 1, Hal. 7-13 